\title{
DFT Study of Bis(Crown-Ether) Analogue of Tröger's Base Complexed with Bisammonium Ions: Hydrogen Bonds
}

\author{
Kwangho Kim and Jong-In Choe* \\ Department of Chemistry, Chung-Ang University, Seon 156-756, Korea. "E-mail: choei@@can.ac.kr \\ Received Jily 3,2006
}

\begin{abstract}
The optimized structures and complexation energies of bis(18-crown-6-ether) analogue (2) of Tröger's base (1) with a series of primary alkylbisammonium ions have been calculated by $D F T$ B3LYP/6-31G(d,p) method. The calculated complexation efficiency $(-142.84 \mathrm{kcal} / \mathrm{mol})$ of 2 for butane-1.4-diylbisammonium guest is better than twice of the value $(-61.40 \mathrm{kcal} / \mathrm{mol})$ for butylammonium ion. The multiple hydrogen-bond abilities for the complexes are described as the function of the length of the alkyl substituents of the bisammonium guests with nonmal-alkyl chain [-( $\left.\left(\mathrm{CII}_{2}\right)_{\mathrm{n}}{ }^{-}, n=4-8\right]$. The longer bisammonium guest shows the stronger hydrogen-bonding characterizations (the distance and the quasi-linear angle of the N-H $\cdots O$ ) to the host 2 than the shorter bisammonium ions. These calculated results agree with the experimental data of the complexation of 2 with bisammonium salts $\left.\left(\mathrm{NII}_{3}\left(\mathrm{CII}_{2}\right)_{\mathrm{n}} \mathrm{NH}_{3}\right] \mathrm{Cl}_{2}\right)$.
\end{abstract}

Key Words : DFT B3LYP/6-3 IG(d,p), Bis(crown-ether), Bisammonium ion, Complex

\section{Introduction}

Molecular recognition of organic ammonium guests is very important in view of many functional biogenic ammonium ions, and a number of sophisticated host systems are derived from crown ethers and calixarenes. ${ }^{1.2}$ Selective endo-calix complexation of alkylammonium jons by functionalized $(1,3)$-p-tert-butylcalix[5]crown ether ${ }^{3}$ and by calix[5]arene-based molecular vessels ${ }^{4}$ have been reported. Finding new receptors ${ }^{5}$ for organic ammonium salts are also important in the perspective that bioactive molecules such as amino acids, peptides and proteins exist partly as ammonium jons in aqueous solutions and for the enantioselective separation of small chiral primary ammonium salts. ${ }^{6}$ It is well established that primary ammonium ions are effective complexation partners for 18 -crown- 6 derivatives. ${ }^{7}$ The bonding forces constitute a combination of charge-dipole and hydrogen-bonding interactions. ${ }^{8}$ Quite a few existing receptors for primary bisammonium ions are based on biscrown ethers.

Previously, we have calculated the structures of $p$-tertbutylcalix[4]crown-6-ether and its alkylammonium complexes by using a $\mathrm{HF} / 6-31 \mathrm{G}$ method. ${ }^{10}$ We have also reported the $a b$ initio calculation results for the energies and structures of p-tert-butylcalix[6](aza)cryptand and its alkylammonium complexes. ${ }^{\text {Ila }}$

The first objective of this research is to calculate the relative binding affinity of various alkylbisammonium ions with bis(18-crown-6-ether) analogue ${ }^{12}(2)$ of Troger's base ${ }^{13}$ (1). Another objective is to compare multiple hydrogenbonding characteristics for the $\left[2+\left(\mathrm{NH}_{3}\left(\mathrm{CH}_{2}\right)_{n} \mathrm{NH}_{3}\right)\right]^{2 /}$ complexes as the function of the length of the primary alky] substituents of the bisammonium guests by using $D F T$ $\mathrm{B} 3 \mathrm{LYP} / 6-31 \mathrm{G}(\mathrm{d}, \mathrm{p})^{14}$ method which includes the effect of an electron correlation and the basis set with a polarization function.

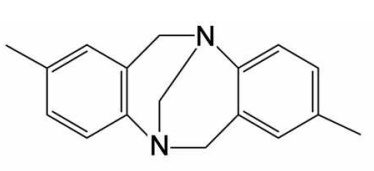

1

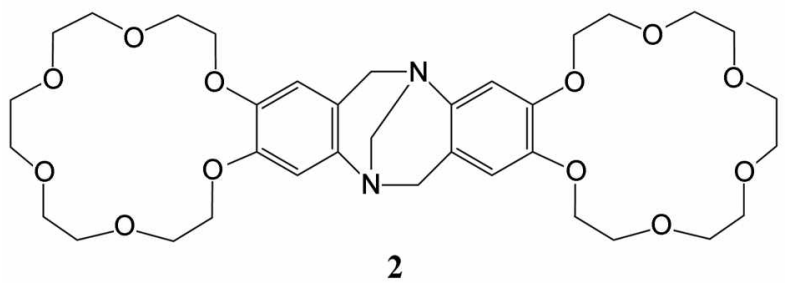

Figure 1. Chemical Drawings of (a) Troger's base 1, (b) bis(18crown-6-ether) analogue 2 of the Troger's base.

\section{Computational Methods}

The initial structures of host 2 and bisammonium ions were created by HyperChem. ${ }^{15}$ In order to find optimized conformations, we executed conformational search by simulated annealing method described in previous research. ${ }^{16}$ DFT B3LYP/6-31G(d,p) full optimization of the structure of host 2 or its bisammonium complex took more than several days to reach the final structure for each complex by using Gaussian $98^{17}$ on supercomputer (NEC SX-7) at the Okazaki National Research Institute of Japan. Normal mode frequencies of the final structures also have been calculated. Each vibrational spectrum shows no negative value of frequency, which suggests that the optimized structure exists in the minimum point.

\section{Results and Discussion}

The B3LYP/6-31G(d,p) complexation energies of the host 2 with the primary bisammonium ions are summarized in 
Table 1. B3LYP/6-31G(d,p) Binding Energies $(\mathrm{kcal} / \mathrm{mol})^{4}$ of Host 2, Alkyl Bisammonium Cations and their Complexes

\begin{tabular}{ccccccc}
\hline Host 2+Guest & \multicolumn{9}{c}{ Guest $^{s}$} \\
\cline { 2 - 7 } Complexation & $n$-Butyl m & $n$-Butyl & $n$-Pentyl & $n$-Hexyl & $n$-Heptyl & $n$-Octyl \\
\hline$\Delta \mathrm{E}(\mathrm{kcal} / \mathrm{mol})^{*}$ & -61.40 & -142.84 & -135.56 & -134.46 & -129.74 & -112.98 \\
$\Delta \Delta \mathrm{E}(\mathrm{kcal} / \mathrm{mol})^{d}$ & & 0.00 & 7.28 & 8.38 & 13.10 & 29.86 \\
\hline
\end{tabular}

"Error limits in these calculations are about $0.01 \mathrm{hcab} / \mathrm{mol}$, $n$-Butyl $\mathrm{m}=n$-butylammonium, $n$-Butyl $=n$-butane-l, 4 diylbisammonium, $n$-Pentyl $=$ $n$-pentane-1,5-diylbisammonium, n-HexyI = n-hexane-1,6-diylbisammonium, $n$-HeptyI = n-heptane-1,7-diylbisammonium, n-OctyI = n-octane-1,7-

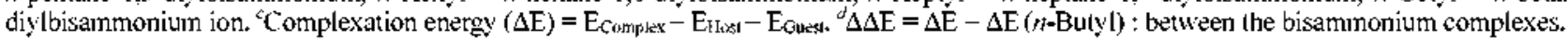

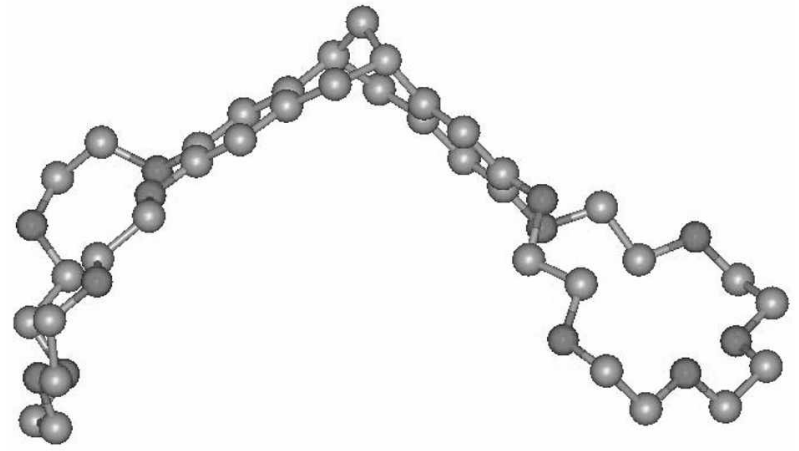

Figure 2. The calculated structure of frec host 2. Figure 2 is drawn without hydrogen atoms for clarity.

Table I. An interesting comparison of the bis- and the monobutylammonium ion tells us that the calculated complexation efficiency $(-142.84 \mathrm{kcal} / \mathrm{mol})$ of 2 for the butane1,4-diylbisammonium guest is better than twice of the value $(-61.40 \mathrm{kcal} / \mathrm{mol})$ for the butylammonium ion. The trend of the complexation efficiencies for 2 using the DFT method is in the order of butane-1,4 > pentane-1,5 $\sim$ hexane-1,6 > heptane-1,7> octane-1,8-diylbisammonium ion.

The DFT optimized structure for the host $\mathbf{2}$ is described in Figure 2 which created by POSMOL ${ }^{18}$ is drawn without hydrogen atoms for clarity. The free host 2 shows the distorted structure of crown-6-ether moieties.

Figure 3 displays the optimized structure of the 2+ $\left[\mathrm{CH}_{3}\left(\mathrm{CH}_{2}\right)_{3} \mathrm{NH}_{3}{ }^{+}\right]$complex. Figures 4 through 8 show the $D F T$ optimized complexes of 2 with various primary bisammonium ions. The shape of the title compound (2) looks more $C_{2 v}$-symmetric upon complexation with a bisammonium ion, due to multiple hydrogen bonds between both of

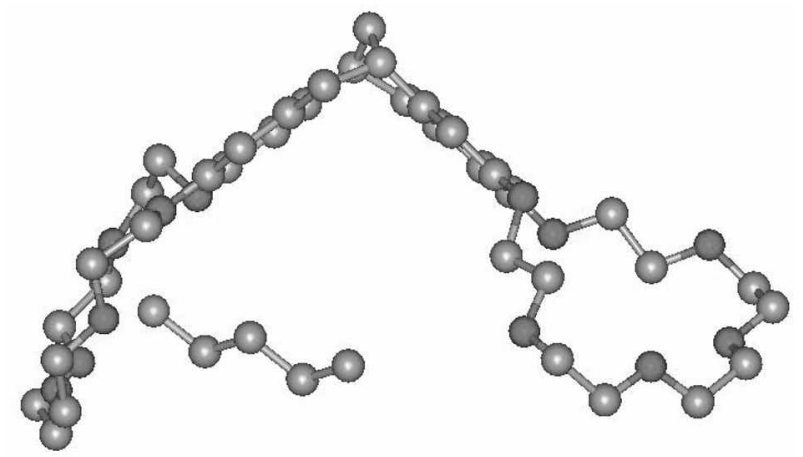

Figure 3. The structure of the $[2+(n \text {-butylammonium })]^{+}$complex $\left(2+\mathrm{CH}_{3}\left(\mathrm{CH}_{2}\right)_{3} \mathrm{NH}_{3}{ }^{+}\right)$.

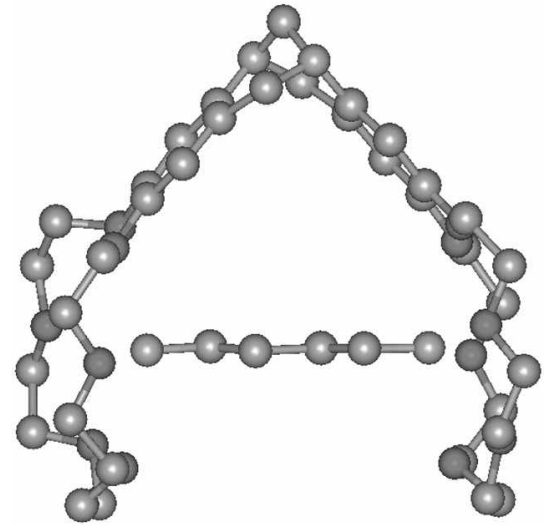

Figure 4. The structure of $\left[2+(\text { butane-1,4-diylbisammonium) }]^{2-}\right.$ complex $\left(2+\mathrm{NH}_{3}{ }^{-}\left(\mathrm{CH}_{2}\right)_{4} \mathrm{NH}_{3}^{-}\right)$.

the crown-6-ether moieties of the host and the double ends of the bisammonium cation. These six hydrogen bonds provide the remarkable stability of the $2+\mathrm{R}_{(}\left(\mathrm{NH}_{3}{ }^{+}\right)$complex. When one observes the Figure 4, two crown-6-ether rings in the $[2+\text { (butane-1,4-diylbisammonium) }]^{21}$ complex become more vertical due to the multiple hydrogen bonds. As the length of the primary alkyl chain of the bisammonium guest gets longer, two 18-crown-6-ether moieties of host 2 become further apart.

Table 2 shows the optimized geometrical parameters $(\mathrm{N} \cdots$ $\mathrm{O}$ and $\mathrm{H} \cdots \mathrm{O}$ distances, $\mathrm{N}-\mathrm{H}$ bond lengths and $\mathrm{N}-\mathrm{H} \cdots \mathrm{O}$ angles) of the bisammonium complexes to understand the strength of the hydrogen bonding. ${ }^{19}$

Table 3 summarizes the individual and the average hydrogen-bond distances from nitrogen atoms of the bisammo-

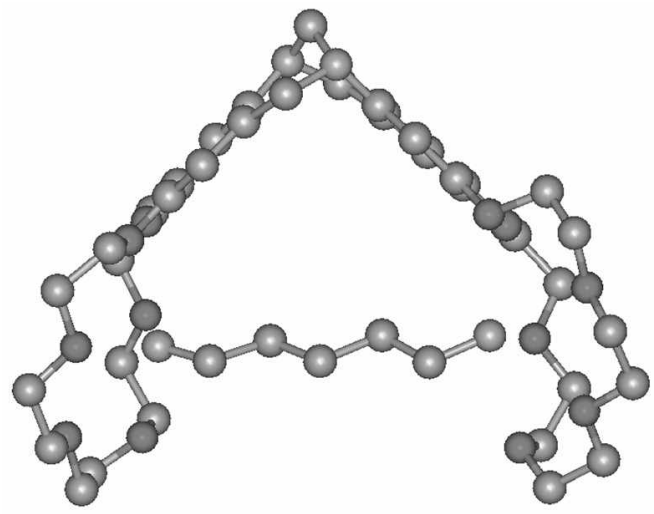

Figure 5. The structure of $[2+(\text { pentane-1,5-diylbisammonium })]^{--}$ complex $\left(2+\mathrm{NH}_{3}{ }^{-}\left(\mathrm{CH}_{2}\right)_{5} \mathrm{NH}_{3}{ }^{-}\right)$. 


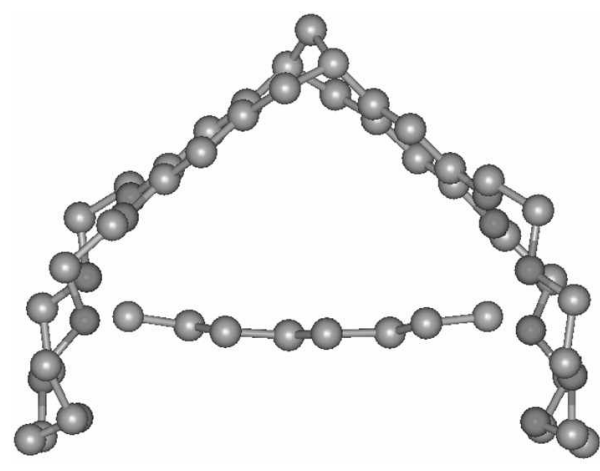

Figure 6. The structure of $[2+(\text { hexanc-1,6-diylbisammonium })]^{2-}$ complex $\left(2+\mathrm{NH}_{3}^{+}\left(\mathrm{CH}_{2}\right)_{6} \mathrm{NH}_{3}^{+}\right)$.

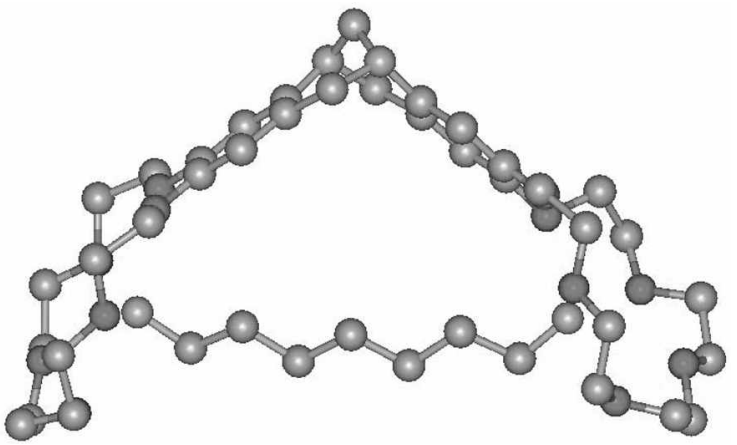

Figure 7. The structure of $[2+(\text { heptane-1,7-diylbisammonium })]^{2-}$ complex $\left(2+\mathrm{NH}_{3}^{+}\left(\mathrm{CH}_{2}\right)_{7} \mathrm{NH}_{3}^{+}\right)$.

nium ion to the oxygen atoms of host 2 . These H-bond distances $[d(\mathrm{~N} \cdots \mathrm{O})=\sim 2.91 \AA]$ are comparable with the experimental values of pentane-1,5-diylbisammonium ( 2.88 $\AA$ ) and hexane-1,6-diylbisammonium $(2.94 \AA)$ complexes of tetra-p-sulfonylcalix[4]arene. ${ }^{20}$ However, our calculated $\mathrm{H}$ bond distance $(2.91 \AA)$ display shorter, therefore, stronger than the values calculated from other primary monoammonium complexes of calix[4]crown-6-ether ${ }^{10}(-3.05 \AA)$ and calix[6](aza)cryptand ${ }^{11 a}(\sim 3.15 \AA)$, and also shorter than the

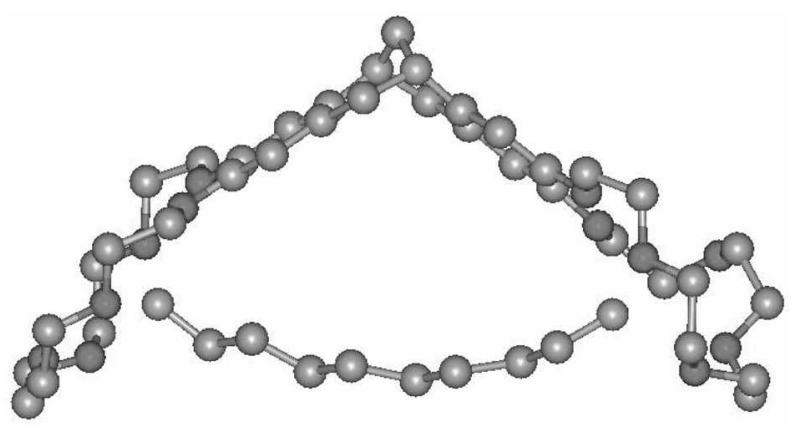

Figure 8. The structure of $[2+(\text { octane-1,8-diylbisammonium })]^{--}$ complex $\left(2+\mathrm{NH}_{3}{ }^{-}\left(\mathrm{CH}_{2}\right)_{8} \mathrm{NH}_{3}^{-}\right)$.

Table 2. Geometrical parameters $(\mathrm{N} \cdots \mathrm{O}$ and $\mathrm{H} \cdots O$ distances, $\mathrm{N}-\mathrm{H}$ bond lengths and $\mathrm{N}-\mathrm{H} \cdots \mathrm{O}$ angles - in $\hat{\Lambda}$ and $\left.{ }^{3}\right)$ of Various Bisammonium Complexes of 2

\begin{tabular}{lllll}
\hline Guest & $\mathrm{N} \cdots \mathrm{O}$ & $\mathrm{H} \cdots \mathrm{O}$ & $\mathrm{N}-\mathrm{H}$ & $\mathrm{N}-\mathrm{H}^{\circ} \cdots \mathrm{O}$ \\
\hline $\mathrm{NH}_{3}\left(\mathrm{CH}_{2}\right)_{4} \mathrm{NH}_{3}$ & 2.911 & 1.886 & 1.037 & 170.822 \\
$\mathrm{NH}_{3}\left(\mathrm{CH}_{2}\right)_{4} \mathrm{NH}_{3}$ & 2.936 & 1.916 & 1.036 & 168.612 \\
$\mathrm{NH}_{3}\left(\mathrm{CH}_{2}\right)_{6} \mathrm{NH}_{3}$ & 2.920 & 1.897 & 1.036 & 170.700 \\
$\mathrm{NH}_{3}\left(\mathrm{CH}_{2}\right)_{7} \mathrm{NH}_{3}$ & 2.904 & 1.872 & 1.035 & 174.549 \\
$\mathrm{NH}_{3}\left(\mathrm{CH}_{2}\right)_{8} \mathrm{NH}_{3}$ & 2.897 & 1.888 & 1.034 & 166.733 \\
\hline
\end{tabular}

"See the footnote b of Táble 1 .

experimental values of calix[6](aza)cryptand ${ }^{1 / \mathrm{t}}(2.97-3.11$ $\AA)$.

The multiple hydrogen-bonding abilities for the complexes are described as the function of the length of the alkyl substituents of the bisammonium guests. The complex with the longer alkyl (heptyl or octyl) chain of the bisammonium ion shows the shorter $\mathrm{H}$-bond distances, therefore, the stronger hydrogen-bondings to 2 than the pentane-1,5diylbisammonium ion. Although the conditions of calculation (in vacuum) and experiment (in $\mathrm{MeOH}-\mathrm{d} 4: \mathrm{CDCl}_{3}$ (1:1)) are different, our DFT calculated results agree with the experimental data of the complexation of 2 with bis-

Table 3. Individual and $\Lambda$ verage Distanecs $(\lambda)$ from the Nitrogen $\Lambda$ tons of Bisammonium Ions to the Oxygen atons of Host 2

\begin{tabular}{cccccccc}
\hline & \multicolumn{9}{c}{ Nitrogen to Ether Oxygen } \\
\hline Guest & N1-O1 & N1-O2 & N1-O3 & N2-O4 & N2-O5 & N2-O6 & Average \\
\hline $\mathrm{NH}_{3}\left(\mathrm{CH}_{2}\right)_{4} \mathrm{NH}_{3}$ & 2.914 & 2.888 & 2.908 & 2.907 & 2.946 & 2.902 & 2.911 \\
$\mathrm{NH}_{3}\left(\mathrm{CH}_{2}\right)_{5} \mathrm{NH}_{3}$ & 3.014 & 2.939 & 2.870 & 2.920 & 2.930 & 2.942 & 2.936 \\
$\mathrm{NH}_{3}\left(\mathrm{CH}_{2}\right)_{6} \mathrm{NH}_{3}$ & 2.951 & 2.928 & 2.882 & 2.951 & 2.928 & 2.882 & 2.920 \\
$\mathrm{NH}_{3}\left(\mathrm{CH}_{2}\right)_{7} \mathrm{NH}_{3}$ & 2.961 & 2.910 & 2.851 & 2.880 & 2.941 & 2.879 & 2.904 \\
$\mathrm{NH}_{3}\left(\mathrm{CH}_{2}\right)_{8} \mathrm{NH}_{3}$ & 2.939 & 2.860 & 2.962 & 2.844 & 2.930 & 2.849 & 2.897 \\
\hline
\end{tabular}

Table 4. Individual and $\Lambda$ verage $A$ ngles $\left({ }^{\circ}\right)$ of the $\mathrm{N}-\mathrm{H}^{*} \mathrm{O}$ atoms of the Bisamınoniun Complexes of 2

\begin{tabular}{|c|c|c|c|c|c|c|c|}
\hline \multicolumn{8}{|c|}{ Nitrogen-H $\cdots$ Oxygen } \\
\hline Guest & $\mathrm{N} 1-\mathrm{H}^{\cdots} \mathrm{O} 1$ & $\mathrm{~N} 1-\mathrm{H} \cdots \mathrm{O} 2$ & $\mathrm{~N} 1-\mathrm{H} \cdots \mathrm{O} 3$ & $\mathrm{~N} 2-\mathrm{H} \cdots \mathrm{O} 4$ & $\mathrm{~N} 2-\mathrm{H} \cdots \mathrm{O}$ & $\mathrm{N} 2-\mathrm{H}^{\cdots} \cdots \mathrm{O} 6$ & Average \\
\hline $\mathrm{NH}_{3}\left(\mathrm{CH}_{2}\right)_{4} \mathrm{NH}_{3}$ & 167.30 & 168.29 & 178.79 & 172.33 & 164.66 & 173.56 & 170.82 \\
\hline $\mathrm{NH}_{3}\left(\mathrm{CH}_{2}\right)_{k} \mathrm{NH}_{3}$ & 171.11 & 152.53 & 170.24 & 174.56 & 171.52 & 171.71 & 168.61 \\
\hline $\mathrm{NH}_{3}\left(\mathrm{CH}_{2}\right)_{6} \mathrm{NH}_{3}$ & 171.14 & 163.72 & 177.23 & 171.13 & 163.73 & 177.24 & 170.70 \\
\hline $\mathrm{NH}_{3}\left(\mathrm{CH}_{2}\right)_{7} \mathrm{NH}_{3}$ & 176.72 & 178.63 & 176.98 & 169.87 & 173.39 & 171.72 & 174.55 \\
\hline $\mathrm{NH}_{3}\left(\mathrm{CH}_{2}\right)_{8} \mathrm{NH}_{3}$ & 173.90 & 160.69 & 174.66 & 168.96 & 170.98 & 151.21 & 166.73 \\
\hline
\end{tabular}


ammonium salts $\left(\left[\mathrm{NH}_{3}\left(\mathrm{CH}_{2}\right)_{n} \mathrm{NH}_{3}\right] \mathrm{Cl}_{2}\right) .^{12}$

Table 4 lists the individual and average angles of the N-H $\cdots \mathrm{O}$ atoms of the bisammonium complexes of 2 . The quasilinear angles with the average range of $166-175^{\circ}$ provide the remarkable strengths of the hydrogen bonds for the bisammonium complexes. These calculated distances and angles of multiple $\mathrm{N}-\mathrm{H} \cdots \mathrm{O}$ hydrogen bonds in the primary bisammonium complexes of 2 may provide an excellent prototype of receptor for bisammonium ammonium salts.

\section{Conclusion}

By using $D F T$ B3LYP/6-31G(d,p) methods we have optimized the structures and have calculated the complexation energies of the bis(18-crown-6-ether) analogue (2) of Tröger's base (1) with various primary bisammonium ions. The complex with the longer alkyl chain (heptyl or octyl) of the bisammonium ion shows the shorter $\mathrm{N}-\mathrm{H} \cdots \mathrm{O}$ distance, therefore, stronger hydrogen bond than the pentane-1,5diylbisammonium ion. The average hydrogen-bonded distance $[d(\mathrm{~N} \cdots \mathrm{O})=\sim 2.91 \AA]$ of five different alkylbisammonium complexes displays shorter than those of the other alkylmonoammonium complexes. The quasi-linear angles of the $\mathrm{N}-\mathrm{H} \cdots \mathrm{O}$ atoms of the bisammonium complexes with the average range of $166-175^{\circ}$ provide the remarkable strengths of the hydrogen bonds for the bisammonium complexes.

Acknowledgement. This research was supported by the Creative Initiative Research Program of Chung-Ang University in 2004. The large portions of the computations were carried out with use of the computer facilities at the Research Center for Computational Science of the Okazaki National Research Institutes in Japan.

\section{References}

1. (a) Molecular Recognition: Chemical and Biochemical Problems, The Proceedings of an Intemational Symposium; Royal Society of Chemistry: Roberts, S. M., Ed.; Dorset Press: Dorset, Great Britain, 1989. (b) Gokel, G. W. In Contprehensive Stpromolecular Chemistry; Lehn, J.-M. Ed.; Pergamon Press: Oxford, U. K., 1996; Vol. 1. (c) Calixarenes 2001; Asfari, Z.; Böhmer, V.; Harrowfield, J.; Vicens, J., Eds.; Kluwer: Dordrecht, 2001.

2. (a) Chang, S.-K.; Hwang, H.-S.; Son, H.; Youk, J.; Kang, Y. S. J. Chem. Soc. Chem. Commun. 1991, 217. (b) Chang, S.-K.; Jang. M.; Han, S. Y.; Lee, J. H.; Kang, M. H.; No, K. T. Chem. Leff. 1992, 1937. (c) Han, S. Y,; Kang, M.-H.; Jung, Y. E.; Chang, S.-K. J. Chem. Soc., Perkin Trans. 2 1994, 835.

3. Pappalardo, S.; Parisi, M. F. J. Org. Chem. 1996, 61, 8724.
4. Amaud-Neu, F.; Fuangswasdi, S.; Noul A.; Pappalardo, S.; Parisii, M. Angen: Chem. Int. Ed. 1998, 37, 112.

5. (a) Yun, S.; Kim, Y.-O.; Kim, D.; Kim, H. G.; Ihm, H.; Kim, J. K.; Lee, C.-W.; Lee, W. J.; Yoon, J.; Oh, K. S.; Yoon, J.; Park, S.-M.; Kim, K. S. Org, Lett. 2003, 5, 471. (b) Kim, K. S.; Lee, J. Y,; Lee, S. J.; Ha, T.-K.; Kim, D. H. J. Am. Chem. Soc. 1994, 116, 7399. (c) Lehninger, A. L. In Biochemistry; Worth Publishers: New York, $1979 ; \mathrm{p} 77$ and $\mathrm{p} 96$.

6. Yamamoto, K.; Yumioka, H.; Okamoto, Y.; Chikamatsu, H. Chem. Soc, Chem. Connitm. 1987, 168.

7. (a) Pedersen, C. J. J. Am. Chem. Soc. 1967, 89, 7017. (b) Lee, C.W.; Jung, E. J.; Lee, S. J.; Ahn, K. H.; Kim, K. S. J. Org. Chem. $2000,65,7225$.

8. (a) Ihm, H.; Yun, S.; Kim, H. G.; Kim, J. K.; Kim, K. S. Org. Lett. 2000, 4, 2897. (b) Izatt, R. M.; Lamb, J. D.; Izatt, N. E.; Rossiter, J. B. E.; Christensen, J. J.; Haymore, B. L. J. Ant. Chem. Soc. $1979,101,6273$.

9. (a) See for instance the reference $\mathrm{I}$, pp $511-532$. (b) Goodman, M. S.; Jubian, V.; Linton, B.; Hamilton, A. D. J. Am. Chem. Soc. $1995,117,11610$.

10. Choe, J.-I.; Chang, S.-K.; Ham, S. W.; Nanbu, S.; Aoyagi, M. Bttl. Korean Chem. Soc. 2001, 22, 1248.

11. Kim, K.; Lee, H. J.; Choe, J.-I. Bull. Korean Chem. Soc. 2005, 26, 645.

12. Hansson, A. P.; Norrby, P.-O.; Waarnmark, K. Tetrahedron Letters $1998,30,4565$.

13. Tröger, J. J. Prakt. Chem. 1887, 36, 225.

14. Lee, C.; Yang, W.; Parr, R. G. P/ns. Rev: B 1988, 37, 785.

15. HyperChem Release 7.5; Hypercube, Inc.: Waterloo, Ontario, 2003.

16. Cho, J.-I.; Kim, K.; Chang, S.-K. Bull. Korean Chem. Soc. 2000, 21,465 .

17. Frisch, M. J.; Trucks, G. W.; Schlegel, H. B.; Scuseria, G. E.; Robb, M. A.; Cheeseman, J. R.; Zakrzewski, V. G; Montgomery, J. A., Jt; Stratmann, R. E.; Burant, J. C.; Dapprich, S.; Millam, J. M.; Daniels, A. D.; Kudin, K. N.; Strain, M. C.; Farkas, O.; Tomasi, J.; Barone, V.; Cossi, M.; Cammi, R.; Mennucei, B.; Pomelli, C.; Adamo, C.; Clifford, S.; Ochterski, J.; Petersson, G. A.; Ayala, P. Y.; Cui, Q.; Morokuma, K.; Malick, D. K.; Rabuck, A. D.; Raghavachari, K.; Foresman, J. B.; Cioslowski, J.; Ortiz, J. V.; Baboul, A. G.; Stefanov, B. B.; Liu, G; Liashenko, A.; Piskorz, P.; Komaromi, I.; Gomperts, R.; Martin, R. L.; Fox, D. J.; Keith, T.; Al-Laham, M. A.; Peng, C. Y.; Nanayakkara, A.; Challacombe, M.; Gill, P. M. W.; Johnson, B.; Chen, W.; Wong, M. W.; Andres, J. L.; Gonzalez, C.; Head-Gordon, M.; Replogle, E. S.; Pople, J. A. Gatssian 98, Revision A.11.3; Gaussian, Inc.: Pittsburgh, PA. 2002.

18. Lee, S. J.; Chung, H. Y; Kim, K. S. Bull. Korean Chem. Soc. 2004, 25, 1061.

19. Jeffrey, G A. An Introdiction to Hydrogen Bonding; Oxford University Press: Oxford, 1997.

20. (a) Silva, E. D.; Nouar, F.; Nierlich, M.; Rather, B.; Zaworotko, M. J.; Barbey, C.; Navaza, A.; Coleman, A. W. Cryst. Eng. 2003, 6, 123. (b) Rather, B.; Moulton, B.; Zaworotko, M. J.; Perret, F.; Morel-Desrosiers, N.; Silva, E. D.; Coleman, A. W. Coyst. Eng. $2003,6,15$. 